New Zealand Journal of Marine and Freshwater Research

\title{
Habitat use of the amphidromous catfish Genidens barbus: first insights at its southern distribution limit
}

Esteban Avigliano , Jorge Pisonero , Ana Méndez , Andrea Tombari \& Alejandra V. Volpedo

To cite this article: Esteban Avigliano, Jorge Pisonero, Ana Méndez, Andrea Tombari \& Alejandra V. Volpedo (2021): Habitat use of the amphidromous catfish Genidens barbus: first insights at its southern distribution limit, New Zealand Journal of Marine and Freshwater Research

To link to this article: https://doi.org/10.1080/00288330.2021.1879178

册 Published online: 12 Feb 2021.

Submit your article to this journal $₫$

Q View related articles $₫$

View Crossmark data $₫$ 


\title{
Habitat use of the amphidromous catfish Genidens barbus: first insights at its southern distribution limit
}

\author{
Esteban Avigliano ${ }^{a, b}$, Jorge Pisonero ${ }^{c}$, Ana Méndez $^{c}$, Andrea Tombari $^{\mathrm{d}}$ and Alejandra \\ V. Volpedo ${ }^{a, b, e}$ \\ ${ }^{\mathrm{a}}$ Facultad de Ciencias Veterinarias. Ciudad Autónoma de Buenos Aires, Universidad de Buenos Aires, \\ Argentina; ${ }^{b}$ CONICET-Universidad de Buenos Aires, Instituto de Investigaciones en Producción Animal \\ (INPA), Ciudad Autónoma de Buenos Aires, Argentina; 'Department of Physics, University of Oviedo, Oviedo, \\ Spain; 'Laboratorio de Tecnología de Alimentos y Biotecnología, Sede Atlántica, Universidad Nacional de Río \\ Negro, Viedma, Río Negro, Argentina; 'Universidad de Buenos Aires, Centro de Estudios Transdisciplinarios \\ del Agua, Ciudad Autónoma de Buenos Aires, Argentina
}

\begin{abstract}
White sea catfish Genidens barbus is an endangered amphidromous species distributed between northeastern Brazil and northern Argentine Patagonia, whose migratory behaviour at the southern end of its range is unknown. Here, the migratory patterns of this species were studied including marine and freshwater (Patagonian stock) environments via otolith core-toedge $\mathrm{Sr} / \mathrm{Ca}$ and $\mathrm{Ba} / \mathrm{Ca}$ profiles. Based on the $\mathrm{Sr} / \mathrm{Ca}$ ratio, all specimens were classified as amphidromous with annual cycles of movement between waters of relatively low to high salinity occurring during spring. The core $\mathrm{Sr} / \mathrm{Ca}$ ratio matched with the reference values for freshwater in all specimens. No evidence of resident freshwater or marine individuals was found. No evident antagonistic relationship was found between both $\mathrm{Sr} / \mathrm{Ca}$ and $\mathrm{Ba} /$ $\mathrm{Ca}$ ratios. $\mathrm{A} \mathrm{Ba} / \mathrm{Ca}$ peak was observed followed by a drop coinciding with the core edge, highlighting the need to evaluate the potential transfer from the yolk, and to understand what factors are linked to the growth marks within the first year of life.
\end{abstract}

\section{ARTICLE HISTORY}

Received 30 November 2020

Accepted 15 January 2021

\section{HANDLING EDITOR}

Neill Herbert

\section{KEYWORDS}

Amphidromous; life history; LA-ICPMS; otolith

microchemistry; Patagonia

\section{Introduction}

White sea catfish Genidens barbus (Lacépède, 1803) is an endangered (MMA 2014) amphidromous fish distributed between northeastern Brazil and northern Argentine Patagonia. Individuals make annual migrations between environments with different salinities from the first year of life (Araújo 1988; Avigliano et al. 2017) and reach sexual maturity between 8.5 and 9 years (Reis 1986a; Velasco et al. 2007). Their reproductive strategy involves the production of a few large eggs and male gastric incubation (Reis 1986a; Araújo 1988). Reproductive migration is associated with a great loss of energy due to the fact that the incubation and transport period of larvae lasts up to 4 months, during that time the individuals do not feed (Reis 1986a; Velasco and Reis 2004). This particular life cycle along with low reproduction rate and high age of first maturation, added to the 
lack of effective fisheries management policies, and has pushed the resource to its collapse, whose exploitation was prohibited since 2015 (MMA 2014). In the last five years, this situation has stimulated a series of studies on its population structure and life history, with the aim of contributing to the administration and recovery of the resource (Avigliano and Volpedo 2016; Di Beneditto et al. 2018). Studies based on otolith and dorsal fin spine chemistry revealed different stocks throughout their distribution, with a geographic dependence on reproductive estuaries or rivers (Avigliano et al. 2015a, 2016, 2019a). Otoliths are acellular calcareous concretions located in the inner ear of fish, which grow continuously and are considered metabolically inert. In many diadromous species, the otolith strontium ( $\mathrm{Sr}$ ) and barium (Ba) concentration is directly related to salinity and their availability in the surrounding water; therefore, they are considered good salinity proxies (Martin and Thorrold 2005; Brown and Severin 2009). Otolith core-to-edge Sr/Ca profiles allow describing four migration patterns in G. barbus from Rio de Janeiro (Brazil) to the La Plata Basin (ArgentinaUruguay) (Avigliano et al. 2015b, 2017). Recently, two studies based on the dorsal spine and otolith chemistry have reported a G. barbus stock in northern Patagonia at the southern end of its distribution (Avigliano et al. 2019, 2020a, 2020b); thus, information is urgently needed to formulate stock-specific conservation strategies (Avigliano et al. 2019).

Based on the recent findings, the goal of this study was to investigate the G. barbus habitat use at its southern distribution limit including the Patagonian stock and the mixing area with the La Plata Basin stock, by using otolith core-to-edge $\mathrm{Sr} / \mathrm{Ca}$ and $\mathrm{Ba} /$ Ca profiles.

\section{Materials and methods}

Fish were collected at the along Argentine coast (Mar de las Pampas-MDP, Argentina; $37^{\circ} 21^{\prime} 44^{\prime \prime} \mathrm{S}-57^{\circ} 02^{\prime} 5.27^{\prime \prime} \mathrm{W}$ ) and the Negro River $20 \mathrm{~km}$ from the river mouth (Patagonian stock, Río Negro, Argentina; 40 $52^{\prime} 32^{\prime \prime} \mathrm{S}$ - 62 $54^{\prime} 34^{\prime \prime} \mathrm{W}$ ) between November 2017 and January 2018 with longlines and fishing rods. Mar de las Pampas (Figure 1(a)) is a coastal marine environment from the Pampean Plain, whose salinities vary from 27 to 34, while Negro River (Figure 1(a)) is a freshwater system that crosses the Patagonian steppe from the Andes to the sea. Fish from the Patagonian stock were caught in freshwater and upper estuary (conductivity: $120-8,060 \mu \mathrm{S} / \mathrm{cm}$, Abrameto et al. 2013). Mean fish total length $\pm \mathrm{SD}$ and range were $31.6 \pm 5.9 \mathrm{~cm}(24.0-41.0 \mathrm{~cm})$ for MDP $(\mathrm{N}=10)$, and $40.8 \pm 4.2 \mathrm{~cm}(32.3-49.1 \mathrm{~cm})$ for Negro River $(\mathrm{N}=13)$. Lapillar otoliths were extracted, decontaminated with 2\% ultrapure nitric acid (Ensure, Merk, Germany), rinsed three times with ultrapure water, and embedded in crystal epoxy resin (Avigliano et al. 2019). A slow-speed saw (Isomet, Hong Kong, China) was used to obtain section the otoliths to the core. These were fixed to glass slides with crystal epoxy resin, and polished using aluminum oxide sandpaper sheets (Avigliano et al. 2019). Finally, otolith sections were rinsed three times, and sonicated for $10 \mathrm{~min}$ with ultrapure water. Fish were aged by counting the growth rings in the otolith sections using a stereomicroscope (Leica EZ4HD, Singapore). Laser Ablation Inductively Coupled Plasma Mass Spectrometry (LAICP-MS) was employed to measure ${ }^{43} \mathrm{Ca},{ }^{88} \mathrm{Sr}$, and ${ }^{138} \mathrm{Ba}$ ion signals in core-to-edge transects (Figure 1(b)), using a $193 \mathrm{~nm}$ ArF Excimer laser (Photon Machines Analyte 




Figure 1. Study area map and Genidens barbus otolith section at the core level. (a) Sampling sites (red arrows). (b) Lapilli otolith sectioned at the core level showing the core-to-edge-laser ablation transects (blue arrow). The red line represents the $\mathrm{Ba} / \mathrm{Ca}$ ratio and the white arrows indicate the annuli position.

G2, USA) coupled to an ICP-QMS (Agilent 7700, Japan). Core-to-edge transects were performed at a scanning speed $15 \mu \mathrm{m} / \mathrm{s}$ with a spot size of $85 \mu \mathrm{m}$ (fluence $=3.75 \mathrm{~J} / \mathrm{cm}^{2}$; pulse repetition rate $=10 \mathrm{~Hz}$ ). Helium was used as carrier gas while argon was added before entering the ICP, which was operated at $1600 \mathrm{~W}$. NIST612 (trace elements in silicate glass) was used to monitor plasma robustness $\left({ }^{238} \mathrm{U} /{ }^{232} \mathrm{Th} \sim 1.2\right)$ and the oxide production rates $\left({ }^{232} \mathrm{Th}^{16} \mathrm{O} /{ }^{232} \mathrm{Th},<0.4 \%\right)$. NIST612 and MACS-3 (trace elements in synthetic calcium carbonate) were measured in triplicate at the beginning and at the end of the analytical session and every 10 otoliths to monitor the elemental fractionation caused by sensitivity drift (Lin et al. 2016). MACS-3 and NIST612 were employed as calibration and secondary standards (Avigliano et al. 2019), respectively, while ${ }^{43} \mathrm{Ca}$ was used as an internal standard (38.3\% weight, Yoshinaga et al. 2000). Recovery rates ranged from 101 to $105 \%$, and the precision based on quadruplicate secondary standard analysis was below 5\%. Sr and Ba concentrations were expressed in relation to $\mathrm{Ca}$. Migratory patterns were classified in amphidromous type a-c and freshwater resident 
according to (Avigliano et al. 2017). Type 'a' was defined as fish whose $\mathrm{Sr} / \mathrm{Ca}$ signature at the beginning of life is compatible with freshwater use and move at least once to a marine environment; type ' $b$ ' corresponded to individuals whose $\mathrm{Sr} / \mathrm{Ca}$ signal at the beginning of life matches with freshwater and then migrate to estuarine water; and type ' $c$ ' was defined as fish whose initial $\mathrm{Sr} / \mathrm{Ca}$ ratio is compatible with estuarine water and move to freshwater, marine or both. Sr/Ca values above $5.98 \mathrm{mmol} / \mathrm{mol}$ were considered as seawater use and those below $3.75 \mathrm{mmol} / \mathrm{mol}$ as incursions to freshwater (Avigliano et al. 2017).

\section{Results}

Otolith $\mathrm{Sr} / \mathrm{Ca}$ ratio varied between 2.01 and $7.74 \mathrm{mmol} / \mathrm{mol}$ for $\mathrm{MDP}$, and from 2.31 to $7.18 \mathrm{mmol} / \mathrm{mol}$ for Negro River. For both sampling sites, the Sr/Ca transects suggested annual cycles of movement between waters of relatively low to high salinity (Figure 2). The core Sr/Ca ratio matched with the reference values for freshwater in all specimens, so they were classified as amphidromous type 'a', except one fish from Negro River (type 'b') (Figure 2(d)). The resident freshwater pattern was not found in the Negro River.

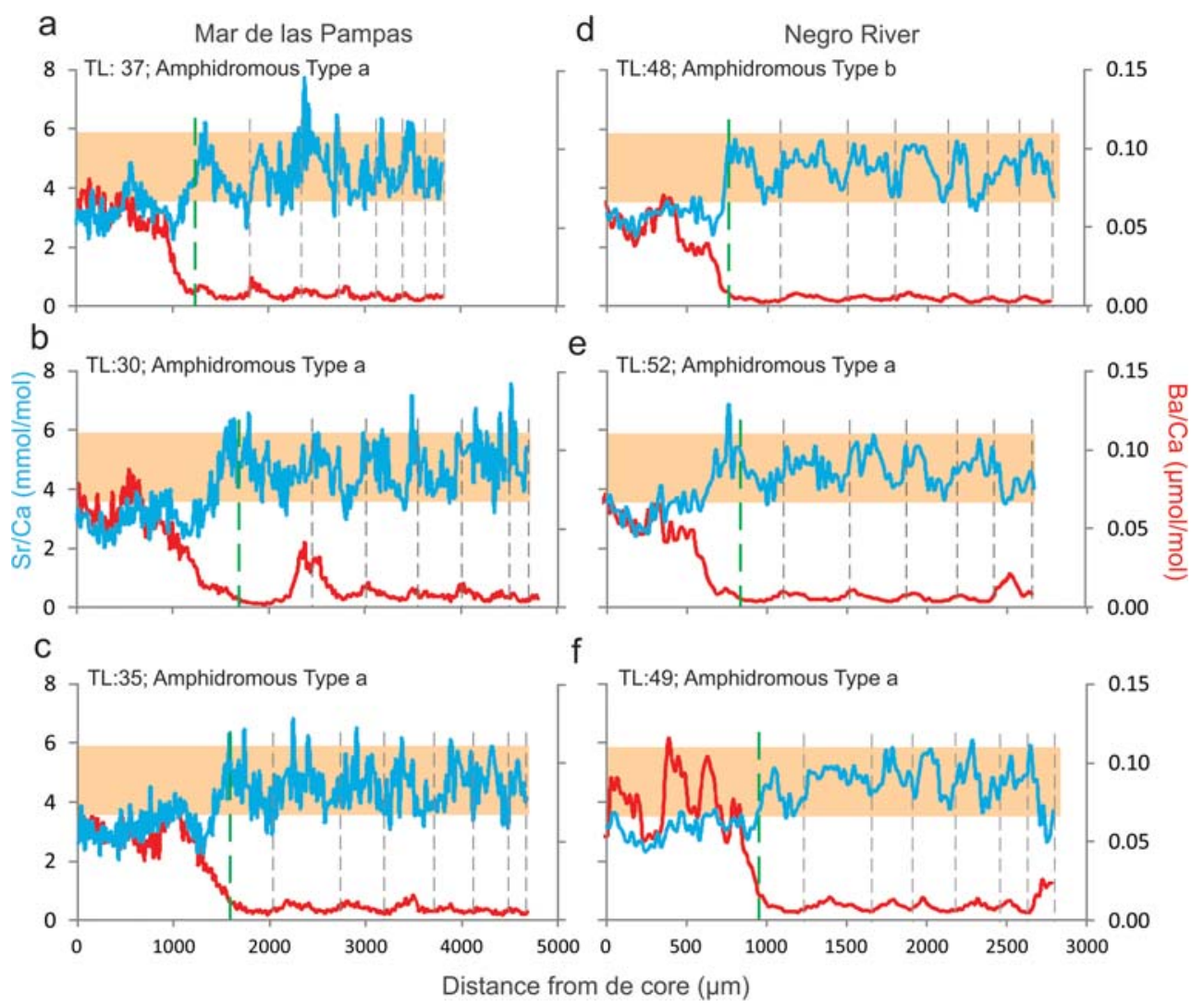

Figure 2. Representative Genidens barbus otolith core-to-edge $\mathrm{Sr} / \mathrm{Ca}$ and $\mathrm{Ba} / \mathrm{Ca}$ profiles. The vertical gray dotted lines indicate the annual marks, while the green line indicates the location of the core edge. The light orange horizontal indicate estuarine environment use. $T L=$ total length $(\mathrm{cm})$. 
Otolith $\mathrm{Ba} / \mathrm{Ca}$ ratio ranged from 0.0016 to $0.15 \mu \mathrm{mol} / \mathrm{mol}$ for MDP and from 0.0030 to $0.14 \mu \mathrm{mol} / \mathrm{mol}$ for Negro River. In all fish analysed, a Ba/Ca peak was observed in the otolith core followed by a strong drop, coinciding with the edge of the core (Figures 1 (b) and 2). No evident antagonistic relationship was found between both $\mathrm{Sr} / \mathrm{Ca}$ and $\mathrm{Ba} / \mathrm{Ca}$ ratios (Figure 2).

\section{Discussion}

This study reports the first insights about G. barbus life history at the southern end of its distribution range, revealing the predominance of the amphidromous type 'a' pattern (fish whose $\mathrm{Sr} / \mathrm{Ca}$ signature at the beginning of life is compatible with freshwater use and move at least once to a marine environment). The predominance of the 'type a' pattern was reported for estuaries in central Brazil, while in southern Brazil and Argentina, populations exhibited a mixture of patterns (Avigliano et al. 2015b, 2017). The resident freshwater pattern was reported only in Lagoa dos Patos (Brazil), representing up to $33 \%$ of the sampled fish (Avigliano et al. 2017). However, the range of life-history patterns is sample size-dependent, so other patterns are expected to be found when more otoliths are analysed.

According to the annual growth marks which are formed during the warm months (December and January) (Reis 1986b and Avigliano et al. 2020a) and the annual Sr/Ca variations found, migrations toward lower salinity environments would occur during the austral spring. This observation is consistent with the annual migratory runs upstream reported for the species, which occur cyclically from the first year in spring (Avigliano et al. 2017; 2020a), suggesting amphidromous migration for feeding, rather than for reproduction.

High $\mathrm{Ba} / \mathrm{Ca}$ values were also reported in the core of the ancient G. barbus from Patagonia (Avigliano et al. 2020a), and even in other species of the same family such as G. genidens Cuvier, 1829 (Maciel et al. 2020) and Cathorops spixii Agassiz, 1829 (Maichak de Carvalho et al. 2020), and in other fish taxa (Ruttenberg et al. 2005). It has been suggested that potential physiological changes (e.g. hatching, flexion, transition to free-embryo, etc.) and maternal effect associated to prolonged yolk-feeding can affect the $\mathrm{Ba}$ incorporation into the otolith core (Kalish 1990; Ruttenberg et al. 2005; Liberoff et al. 2014). Because the reproductive strategy of G. barbus involves a prolonged yolk-sac period, these hypotheses could be plausible.

\section{Conclusions}

All specimens were classified as amphidromous with annual cycles of movements between environments with different salinity during spring and no evidence of resident freshwater or resident marine individuals was found. This report raises new unknowns that need to be resolved to improve the potential of the otolith chemistry as a habitat proxy for G. barbus. It is necessary to evaluate the potential transfer of trace element from the yolk to the otolith core and to understand what factors are linked to the core mark. Is it possible that this mark corresponds to the transition to free-embryo stage? If so, could the strong $\mathrm{Ba}$ drop be an indication of this event? Since this species has 
such large eggs, it should be possible to (1) analyse their chemistry, and (2) dissect otoliths out of the embryos to perform chemistry on.

\section{Acknowledgements}

Authors are grateful to N. F. Schenone and S. Gironde who helped in collections, and ScientificTechnical Services (SCTs) of the Oviedo University for the analytical support. The authors thank the four reviewers whose comments and suggestions helped improve and clarify this manuscript.

\section{Disclosure statement}

No potential conflict of interest was reported by the author(s).

\section{Funding}

This work was supported by the Programa Becar-Ministerio de Educación de Argentina under Grant Becar2019; Government of Principality of Asturias (Spain) under Grant IDI/2018/ 000186-Fondos Feder; Agencia Nacional de Promoción Científica y Tecnológica under Grant PICT 2015-1823; and Universidad de Buenos Aires under Grant UBACyT 20020150100052BA; Fondo para la Investigación Científica y Tecnológica.

\section{Data availability statement}

The data are available upon request to the corresponding author.

\section{References}

Abrameto MA, Dapeña C, Aldalur B, Caro A, Cecchini V, Fernández C, Szmulewicz M, Travaglio M, Abate S, Molina LM. 2013. Caracterización química e isotópica preliminar del agua superficial y subterránea en el Valle inferior del río Negro, Argentina. In: González N, Kruse EE, Trovatto MM, Laurencena P, editor. Patricia (Ed) Agua subterránea recurso estrategico. 2nd ed. La Plata: Edulp; p. 22-33.

Araújo FG. 1988. Distribuição, abundância relativa e movimentos sazonais de bagres marinhos (Siluriformes, Ariidae) no estuário da Lagoa dos Patos (RS), Brasil. Revista Brasileira de Zoologia. 5(4):509-543.

Avigliano E, Carvalho B, Velasco G, Tripodi P, Vianna M, Volpedo AV. 2016. Nursery areas and connectivity of the adults anadromous catfish (Genidens barbus) revealed by otolith-core microchemistry in the south-western Atlantic Ocean. Marine and Freshwater Research. 68(5):931940.

Avigliano E, Leisen M, Romero R, Carvalho B, Velasco G, Vianna M, Barra F, Volpedo AV. 2017. Fluvio-marine travelers from South America: Cyclic amphidromy and freshwater residency, typical behaviors in Genidens barbus inferred by otolith chemistry. Fisheries Research. 193 (April):184-194. doi:10.1016/j.fishres.2017.04.011.

Avigliano E, Maichak de Carvalho B, Miller N, Córdoba Gironde S, Tombari A, Limburg K, Volpedo AV. 2019. Fin spines chemistry as a non-lethal alternative to otoliths for habitat and stock discrimination: comparison between structures for an endangered catfish species. Marine Ecology Progress Series. 614:147-157.

Avigliano E, Martínez G, Stoessel L, Méndez M, Bordel N, Pisonero J, Volpedo AV. 2020a. Otoliths as indicators for fish behaviour and procurement strategies of hunter-gatherers in North Patagonia. Heliyon. 6(3):e03438. 
Avigliano E, Miller N, Maichak fr Carvalho B, Córdoba S, Tombari A, Volpedo VA. 2020b. Fin spine metals by LA-ICP-MS as a method for fish stock discrimination of Genidens barbus in anthropized estuaries. Fisheries Research. 230(May):105625. doi:10.1016/j.fishres.2020.105625.

Avigliano E, Velasco G, Volpedo AV. 2015a. Use of lapillus otolith microchemistry as an indicator of the habitat of Genidens barbus from different estuarine environments in the southwestern Atlantic Ocean. Environmental Biology of Fishes. 98(6):1623-1632. http://link.springer.com/ 10.1007/s10641-015-0387-3.

Avigliano E, Velasco G, Volpedo AV. 2015b. Assessing the use of two southwestern Atlantic estuaries by different life cycle stages of the anadromous catfish Genidens barbus (Lacépède, 1803) as revealed by Sr:Ca and Ba:Ca ratios in otoliths. Journal of Applied Ichthyology. 31(4):740-743.

Avigliano E, Volpedo A. 2016. A review of the application of otolith microchemistry toward the study of Latin American fishes. Reviews in Fisheries Science and Aquaculture. 24(4):369-384.

Di Beneditto APM, Tavares MTM, Monteiro LR. 2018. Isotopic niche of the catfishes bagre bagre and Genidens barbus in a coastal area of south-eastern Brazil. Biota Neotropica. 18(3): e20180527.

Brown RJ, Severin KP. 2009. Otolith chemistry analyses indicate that water Sr:Ca is the primary factor influencing otolith $\mathrm{Sr}$ :Ca for freshwater and diadromous fish but not for marine fish. Canadian Journal of Fisheries and Aquatic Sciences. 66(10):1790-1808.

Kalish J. 1990. Use of otolith microchemistry to distinguish the progeny of sympatric anadromous and non-anadromous salmonids. Fishery Bulletin. 88:657-666.

Liberoff AL, Miller JA, Riva-Rossi CM, Hidalgo FJ, Fogel ML, Pascual MA, Tierney K. 2014. Transgenerational effects of anadromy on juvenile growth traits in an introduced population of rainbow trout (Oncorhynchus mykiss). Canadian Journal of Fisheries and Aquatic Sciences. 71(November 2013):398-407.

Lin J, Liu Y, Yang Y, Hu Z. 2016. Calibration and correction of LA-ICP-MS and LA-MC-ICP-MS analyses for element contents and isotopic ratios. Solid Earth Sciences. 1(1):5-27.

Maciel TR, Avigliano E, Maichak de Carvalhoc B, Miller N, Viannaa M. 2020. Population structure and habitat connectivity of Genidens genidens (Siluriformes) in tropical and subtropical coasts from Southwestern Atlantic. Estuarine, Coastal and Shelf Science. 242:106839.

Maichak de Carvalho B, Pisonero J, Mendez A, Volpedo AV, Avigliano E. 2020. Spatial environmental variability of natural markers and habitat use of Cathorops spixii in a neotropical estuary from otolith chemistry. Journal of the Marine Biological Association of the UK. 100(5):783-793.

Martin GB, Thorrold SR. 2005. Temperature and salinity effects on magnesium, manganese, and barium incorporation in otoliths of larval and early juvenile spot Leiostomus xanthurus. Marine Ecology Progress Series. 293:223-232.

MMA. 2014. Ministério do Meio Ambiente do Brasil. Portarias Nos. 443, 444, 445, de 17 de Dezembro de 2014, Diário Oficial da União [Internet]. Brasilia: Ministério do Meio Ambiente. http://www.icmbio.gov.br/portal/images/stories/biodiversidade/fauna-brasileira/ avaliacao-do-risco/PORTARIA_No_445_DE_17_DE_DEZEMBRO_DE_2014.pdf.

Reis EG. 1986a. Reproduction and feeding habits of the marine catfish, Netuma barba (Siluriformes, Ariidae), in the estuary of the Patos Lagoon (Brazil). Atlantica. 8:35-55.

Reis EG. 1986b. Age and growth of the marine catfish, Netuma barba (Siluriformes, Ariidae), in the estuary of the Patos Lagoon (Brasil). Fishery Bulletin. 84(3):679-686.

Ruttenberg BI, Hamilton SL, Hickford MJH, Paradis GL, Sheehy MS, Standish JD, Ben-Tzvi O, Warner RR. 2005. Elevated levels of trace elements in cores of otoliths and their potential for use as natural tags. Marine Ecology Progress Series. 297:273-281.

Velasco G, Reis E. 2004. Changes in growth seasonality throughout Netuma barba (Lacépède, 1803) (Siluriformes, Ariidae) ontogeny. Brazilian Journal of Biology. 64(4):913-914.

Velasco G, Reis EG, Vieira JP. 2007. Calculating growth parameters of Genidens barbus (Siluriformes, Ariidae) using length composition and age data. Journal of Applied Ichthyology. 23:64-69.

Yoshinaga J, Nakama A, Morita M, Edmonds JS. 2000. Fish otolith reference material for quality assurance of chemical analyses. Marine Chemistry. 69(1-2):91-97. 